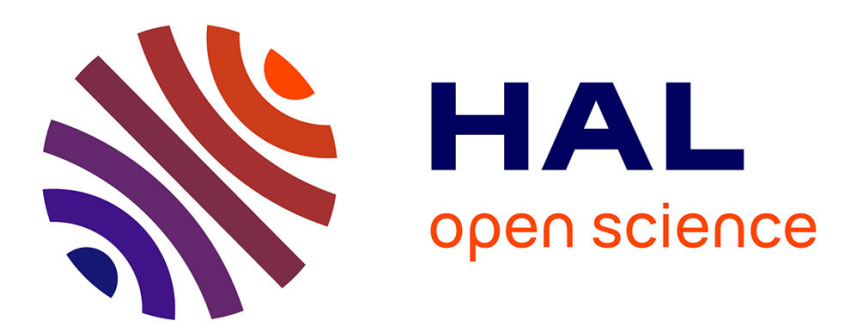

\title{
The effect of proximity to a honeybee apiary on bumblebee colony fitness, development, and performance
}

Twfeik Elbgami, William Kunin, William Hughes, Jacobus Biesmeijer

\section{To cite this version:}

Twfeik Elbgami, William Kunin, William Hughes, Jacobus Biesmeijer. The effect of proximity to a honeybee apiary on bumblebee colony fitness, development, and performance. Apidologie, 2014, 45 (4), pp.504-513. 10.1007/s13592-013-0265-y . hal-01234744

\section{HAL Id: hal-01234744 \\ https://hal.science/hal-01234744}

Submitted on 27 Nov 2015

HAL is a multi-disciplinary open access archive for the deposit and dissemination of scientific research documents, whether they are published or not. The documents may come from teaching and research institutions in France or abroad, or from public or private research centers.
L'archive ouverte pluridisciplinaire HAL, est destinée au dépôt et à la diffusion de documents scientifiques de niveau recherche, publiés ou non, émanant des établissements d'enseignement et de recherche français ou étrangers, des laboratoires publics ou privés. 


\title{
The effect of proximity to a honeybee apiary on bumblebee colony fitness, development, and performance
}

\author{
Twfeik ElbGami $^{1}$, William E. Kunin ${ }^{1}$, William O. H. Hughes ${ }^{2}$, \\ Jacobus C. BIESMEIJER ${ }^{3}$ \\ ${ }^{1}$ School of Biology, University of Leeds, Leeds LS2 9JT, UK \\ ${ }^{2}$ School of Life Sciences, University of Sussex, Brighton BN1 9QG, UK \\ ${ }^{3}$ Naturalis Biodiversity Center, Postbus 9517, 2300 RA, Leiden, Netherlands
}

Received 24 April 2013 - Revised 5 December 2013 - Accepted 26 December 2013

\begin{abstract}
Competition between managed honeybees and wild pollinators is thought to be a key factor in structuring foraging communities on flowers. The majority of studies have focused on impacts such as floral visitation rates and resource overlap. However, direct measurement of fitness is required to fully assess the impacts of competition. We compared in 2 years the weight and reproductive success of bumblebee colonies located at two sites that were either close to or far from a large honeybee apiary, and which were located in the same landscape and with access to similar floral resources. We found that bumblebee colonies located at the site near the honeybee apiary gained less weight, and produced fewer and smaller queens, in both years than colonies at the site far from the apiary. The ratio of queen weight/size was lower in the colonies near honeybees in 1 year, while males were smaller and offspring sex ratio more male biased in colonies close to honeybees than in those far from honeybees. Proximity to managed honeybee hives was therefore associated with significantly reduced fitness of bumblebee colonies, but studies from many more sites are needed to confirm the effect.
\end{abstract}

pollinator ecology / competition / bees / Bombus terrestris / Apis mellifera

\section{INTRODUCTION}

Competition between managed honeybees (Apis mellifera) and wild pollinators is thought to be a key factor in structuring foraging communities on flowers (Corbet et al., 1995; Denno et al., 1995). Honeybees are documented to compete with native flower visitors for

Electronic supplementary material The online version of this article (doi:10.1007/s13592-013-0265-y) contains supplementary material, which is available to authorized users.

Corresponding author: W. Hughes,

William.Hughes@sussex.ac.uk

Manuscript editor: James Nieh resources (Sugden and Pyke, 1991; Gross, 1993; Oldroyd et al., 1994; Butz, 1997). Some studies have shown an overlap in resource use and decreasing abundance of wild pollinators in the presence of honeybees, especially when resources are limited (Roubik, 1983; Schaffer et al., 1983). Managed honeybees can competitively displace wild pollinators from floral resources through exploitative competition (Ginsberg, 1983; Wilms and Wiechers, 1997; Goulson et al., 2002b). However, there is little clear evidence that competition from managed honeybees has negative impacts on the reproductive success or the survival of other flower visitors (Sugden et al., 1996; Butz, 1997). Only few studies have found evidence for impacts at 
the population level (e.g., Wenner, 1992; Roubik and Wolda, 2001). Although honeybees are native in Europe and have coevolved with other native pollinators, there is still the potential for strong competition because beekeeping activities can produce unnaturally high local densities of honeybees (Goulson, 2004), that may put additional pressure on other pollinators (Walther-Hellwig et al., 2006).

Bumblebees (Bombus spp.) are major pollinators in temperate regions of the northern hemisphere (Fontaine et al., 2006). There is substantial evidence that many bumblebee species have declined in Europe, North America, and Asia in recent decades due to stresses such as habitat loss and pathogen spillover from commercial bees (Kosior et al., 2007; Colla and Packer, 2008; Williams and Osborne, 2009, Cameron et al., 2011; Szabo et al. 2012; Graystock et al. 2013a). However, there is evidence that competition with managed honeybees can also have negative effects on bumblebees, either in isolation or by reinforcing any effect of habitat loss. For example, Thomson (2004) found that foraging rates and reproductive success of Bombus occidentalis colonies were significantly reduced as a result of proximity to honeybee hives in California. Moreover, Walther-Hellwig et al. (2006) reported that short-tongued bumblebees, Bombus terrestris, avoided foraging at sites close to honeybee hives, while longer-tongued bumblebee species switched to foraging later in the day and shifted to less preferred floral resources. Thomson (2006) also found a significant niche overlap between the foraging preferences of native bumblebees and introduced honeybees, which was as high as 80-90\% during periods of resource scarcity.

Parameters such as a reduction in visitation rate or increasing overlap in floral resource harvesting can be used as an indicator of the potential for competition between honeybees and native bees. However, to confirm the detrimental impact of managed honeybees, an evaluation of wild bee fecundity, survival, or population density is essential (Paini, 2004). If managed, honeybees have a negative impact on bumblebees; they will reduce colony develop- ment and colony productivity. Such effects may include changes in the number, size, or sex ratio of reproductives. Larger body size confers fitness benefits in insects in general (Blanckenhorn, 2000), including in terms of male mating success (Thornhill and Alcock, 2000), and is an important predictor of hibernation success in bumblebee queens (Holm, 1972; Beekman et al., 1998). As queens require a greater investment of resources to produce than males (Beekman and van Stratum, 1998), it can be hypothesized that colony sex investment ratios should become more male biased in colonies under stress (e.g., close to a honeybee apiary). Bumblebee colonies undergo a switch point from the production of workers to reproductives, the timing of which appears to be endogenous (Holland et al. 2013), and effects of competition on the ratio of workers/reproductives are therefore less likely.

In this study, we assess whether and how the proximity to a honeybee apiary affects bumblebee colony development and reproductive success, as well as colony weight, individual weight, and foraging activity. We addressed this by direct comparison of fitness traits of bumblebee colonies located at a site close to a honeybee apiary and others placed at a site further away from the apiary. Other than the presence of the honeybee apiary, the two sites were located in the same landscape and provided access to similar floral resources. We hypothesized that bumblebee colonies near the honeybee apiary would experience a resource shortage and would consequently produce fewer and lighter queens and males, a lower queen weight/size ratio (because of lower fat reserves) as well as a higher male/ female ratio (a response to lower resource availability). Furthermore, we hypothesized that the overall weight of bumblebee colonies near honeybees would be less than that far away from honeybees.

\section{MATERIALS AND METHODS}

The study was carried out in 2010 and 2012 at the University of Leeds Field Station, Headley Hall 
Farm, Tadcaster, West Yorkshire at $53^{\circ} 52^{\prime} \mathrm{N}, 1^{\circ} 20^{\prime}$ $\mathrm{W}$. In each year, a set of five bumblebee colonies was placed within $5 \mathrm{~m}$ of the honeybee apiary and another set of five colonies was located $1 \mathrm{~km}$ away from the apiary. The apiary contained 50 standard-sized $A$. mellifera hives. The surrounding landscape and availability of forage was similar at both locations (Figure ESM1), consisting predominantly of farmland used for winter wheat and spring barley, with oilseed rape peas and potatoes as break crops, and some areas of permanent pasture, as well as several agro-forestry plots, a 1.5-ha field sown for nectar/ pollen production (borage, red clover, Phacelia, and mustard) and hedgerows. The experiment was performed between the end of July and 1st September in 2010, and between 1st June and the middle of July in 2012. Colonies of the native UK bumblebee, Bombus terrestris audax (Hymenoptera: Apidae) were supplied by Biobest via Agralan UK. Bumblebee colonies (50-60 workers + one queen/colony at the time of supplying) were provided with ready-to-use sugar solutions as food which were left inside the colonies for 1 day, then removed. The colonies were left closed for 1 day to settle down before the experiments started. Then, the colonies were opened and bees were allowed to forage naturally for 6 weeks, after which, the experiments were ended. Each colony was weighed weekly and colonies were freeze-killed at the end of the experiment. To weigh the colonies, we closed the entrances of the colonies at the end of the day with a bee-lock (a flight opening with a coned tube). In the early morning of the next day, we weighed the colonies and left the entrance closed for about $1 \mathrm{~h}$ to let the bees settle down, before then, opening the entrances to allow the bees to forage again. To ensure that new queens would not escape from the hives while permitting the smaller workers to exit and enter freely, we adjusted the hive entrance diameter to $7 \mathrm{~mm}$ (Goulson et al., 2002a).

Colony reproductive success was measured after the 6-week period by counting the number and size of all emerged males and new queens (gynes) in the colonies. To assess the colony size, the number of workers was counted. The size of workers was estimated by weighing 20 randomly chosen workers. The size of all queens and males was estimated by weighing and by measuring their thorax width as the shortest distance between the bases of the tegula with a digital vernier caliper accurate to $0.01 \mathrm{~mm}$ (Goulson et al., 2002a; Peat et al., 2005b). Because of the possibility for some males or workers to escape from the nest and of natural mortality of bumblebee workers throughout the season, we also counted all closed and opened pupal cocoons in each colony. However, as it is less likely for new queens to escape from hives because of the small entrance, queens were counted as the number of emerged adults plus the number of only closed pupal cocoons (which were assumed to be queens at this stage in the lifecycle). The ratio between queen weight and size (weight/size), as a potential indication of the fat content stored by queens and which can be consumed during hibernation (Holm, 1972; Inoue, 2011), was calculated by simply dividing queen weight by queen size.

In 2010 , colony foraging activity was evaluated by filming the hive entrances, using a digital video camera, for $1 \mathrm{~h}$ six times, at 4-6-day intervals to record the number of out-going bees (number of bees departing the hive/10-min "foraging trip"). We hypothesized that colonies close to honeybees would suffer from food shortage as a result of the presence of honeybees, and thus would have to send out more bees to obtain the colony's food requirements so that the number of departing bees (foraging trips) would be greater in the colonies close to honeybee hives.

To test our hypotheses, we compared the different fitness parameters between colonies close to or far from the honeybee apiary using generalized linear models with a gamma distribution, log link function, colonies as replicates (with workers, males, or queens, averaged within colonies for the individual size and weight variables), and proximity to the apiary as the independent factor. We used repeated-measure ANOVAs to compare the changes in colony weight over time, between colonies close to or far from the honeybee apiary because weight data met the assumptions of normality and homogeneity of variances. As we tested each variable separately and there were therefore relatively many tests, we corrected for multiple comparisons using the sequential Bonferroni method.

\section{RESULTS}

Colonies gained weight throughout the experimental period in both years and at both sites (Figure 1). In 2010, at the beginning of the 


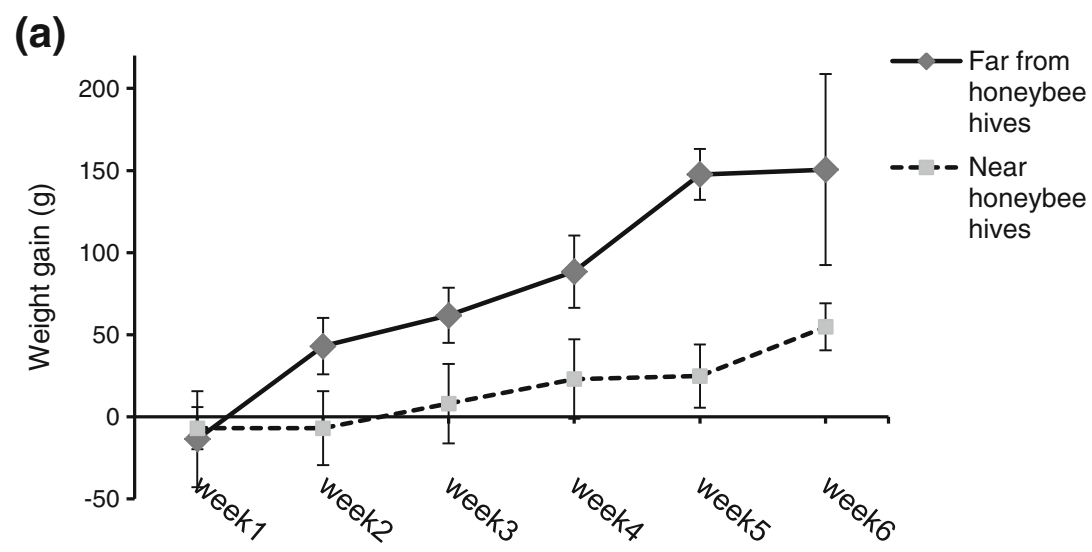

(b)

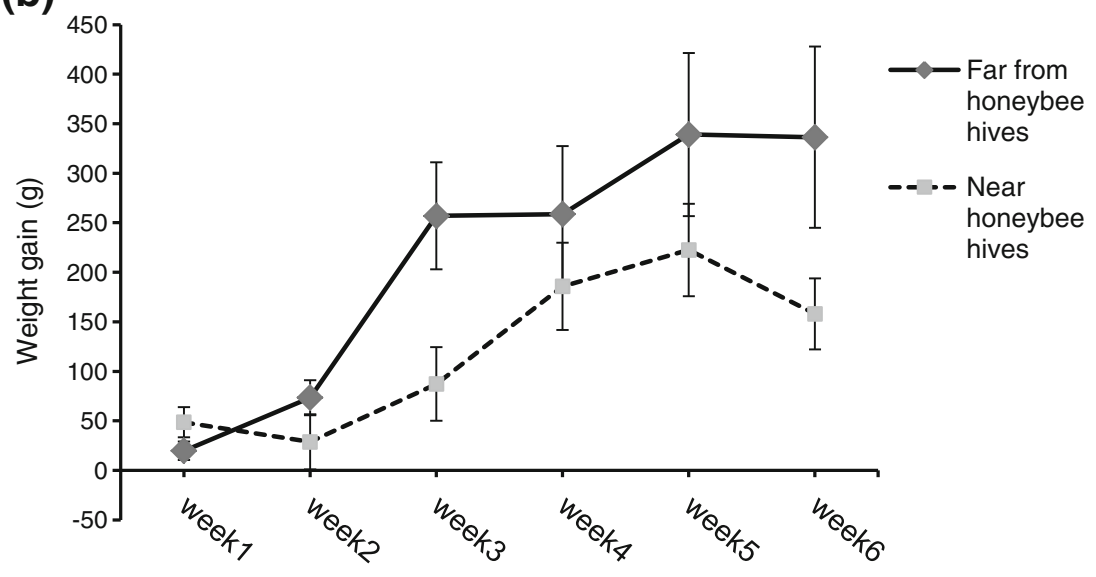

Figure 1. The mean $\pm \mathrm{SE}$ weight gain of bumblebee colonies that were located either near to or far from a honeybee apiary in 2 years, a 2010 and b 2012. Data are from five colonies at each location in each year.

experiment, the average biomass of the colonies far from the apiary was $853 \pm 1.9 \mathrm{~g}($ mean $\pm \mathrm{SE})$ and of colonies close to the apiary was $878 \pm$ $14.2 \mathrm{~g}$ (mean $\pm \mathrm{SE}$ ), with their weight increasing by the end of the experiment to $1,003 \pm 59.8$ and $932 \pm 12.5 \mathrm{~g}$, respectively. Therefore, by the end of the experiment, the colonies further away from honeybee hives gained about $151 \mathrm{~g}$ while colonies nearby the honeybees gained only $55 \mathrm{~g}$ (Figure 1a). In 2012, all colonies also gained weight throughout the study period; however, colonies far from the apiary gained more than colonies close to the apiary by up to $178 \mathrm{~g}$ (Figure 1b). There was a significant effect of proximity to apiary on weight gain over time in $2010\left(F_{1,8}=5.91, P=0.041\right)$, but a marginally non-significant effect in $2012\left(F_{1,8}=4.83, P=\right.$ $0.059)$. Although colonies in both sites gained weight with time, colonies far from honeybees gained significantly more weight with time than those located close to the honeybee apiary.

\subsection{Colony reproductive success}

Reproductive output varied substantially between colonies close to or far from the apiary in both years. All colonies produced males and at least one new queen (gyne), except one colony 
close to honeybee hives in 2012 which did not produce any new queens. By the end of the experimental periods, the total number of queens produced was higher in the sites further from honeybees (significantly so in 2010, but not in 2012 after Bonferroni correction; Table I). The size of bumblebee queens, based on thorax width, was significantly reduced in the colonies close to the apiary compared to colonies far from it, in both years (Table I), while the weight of the queens was also higher in the colonies far from the apiary than in colonies close to the apiary in both years, although this was significantly so only in 2010 (Table I). In 2010, queen weight/size ratio was significantly lower in the queens produced in the colonies close to the honeybee apiary than in the colonies far from it (Table I). In contrast, in 2012, the ratio was very similar between the colonies near the honeybee hives and those further away.

All colonies produced males and although the number of males produced varied between colonies, sites, and years (Table I), no significant difference in male numbers was evident between colonies close to or far from the apiary in either year. Males produced by colonies far from the honeybee apiary were slightly larger (in terms of thorax width) compared to those produced in colonies near the apiary in 1 year, while male weight was very similar between the two sites (Table I). The male/queen ratio was significantly higher in the colonies located near honeybee hives than in those further away in 2010, but not 2012 (Table I). It should be noted that in 2010 , the male/queen ratio was extremely high (11.9:1) in the colonies near honeybees compared to the colonies far from honeybees (2.5:1), whereas the male/queen ratio in 2012 was less divergent (3.7:1 and 1.6:1; Table I).

\subsection{Worker size and activity}

Workers from colonies far from the apiary were significantly lighter than workers from the colonies close to the honeybee hives in 2010, but not in 2012 (Table I). The number of workers was higher in the colonies further away from the honeybee apiary, but the difference was not significant in either year (Table I). The number of bees that left the colony on foraging trips after 2 weeks was slightly, but not significantly, higher for colonies near to the apiary than those far from the apiary (Figure 2). The foraging activity from all colonies was reduced after 4 weeks, but to a much greater extent in colonies near to the apiary in which the number of trips was less than half of that after 2 weeks (Figure 2). After 4 weeks, there were, accordingly, significantly more foraging trips being made by bees in colonies far from the apiary than those near to the apiary $(t=3.7$, $\mathrm{df}=8, P=0.006)$.

\section{DISCUSSION}

The results suggest that proximity to a honeybee apiary can significantly reduce the fitness of bumblebee colonies. Bumblebee colonies located at a site close to the honeybee apiary had lighter workers and produced fewer, smaller queens in both years, and had queens with lower weight and weight/size ratio in 1 of the 2 years. Although the data are from only two sites, these sites were surrounded by essentially the same foraging landscape and differed in no obvious way other than the presence of the honeybee apiary. While the data therefore does not definitively prove that the reduced fitness of bumblebee colonies at the site close to the apiary was due to the honeybees, as opposed to some other unknown factor, it does seem most plausible that the presence of honeybees negatively affected bumblebee colony growth and fitness. The negative effect of honeybees appeared to be generally greater in 2010 than in 2012, suggesting that the impact of honeybees can vary depending perhaps on temporal variation in weather conditions, flower availability, pesticide exposure, or other environmental factors.

Bumblebee colonies located far from the apiary gained significantly more weight than colonies close to the apiary in both years, which will have been due to increases in the number or weight of bees, or food stored inside the colony. The overall weight gained by the colony is an indicator of 


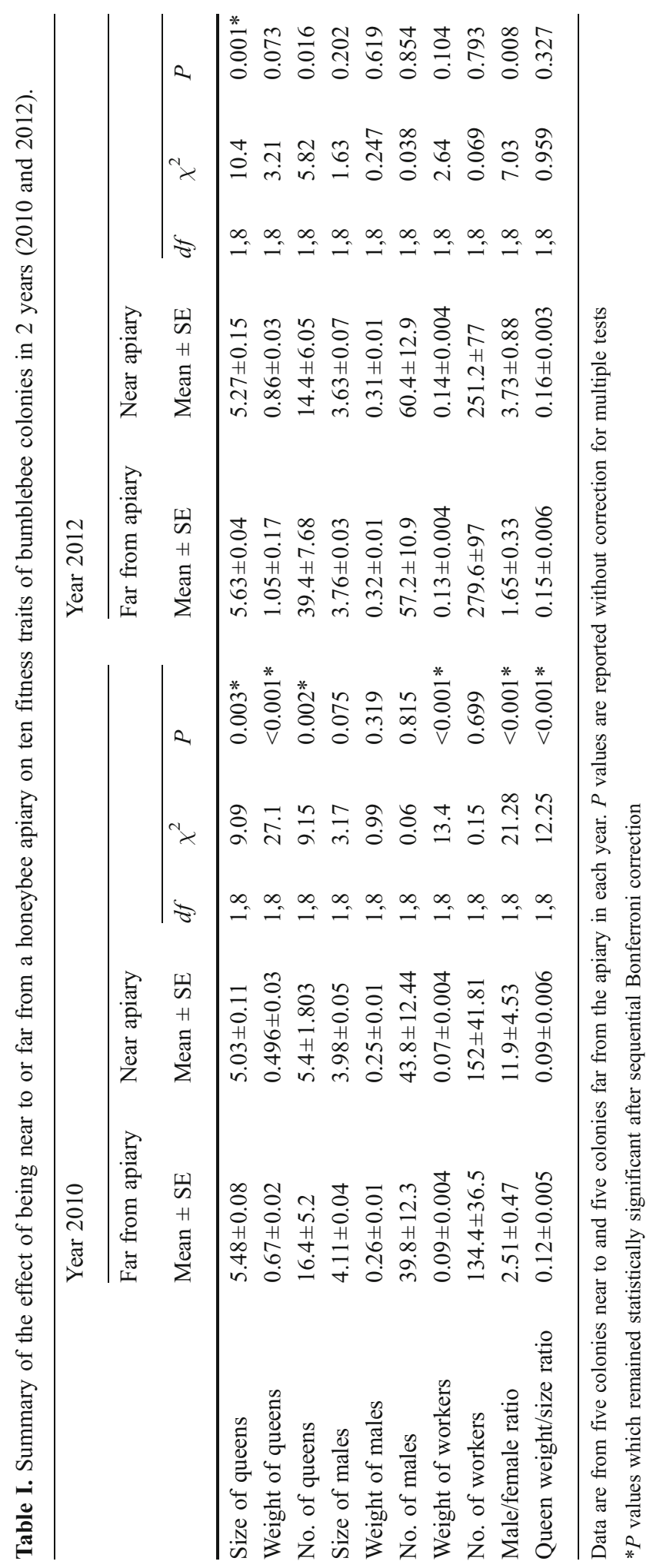




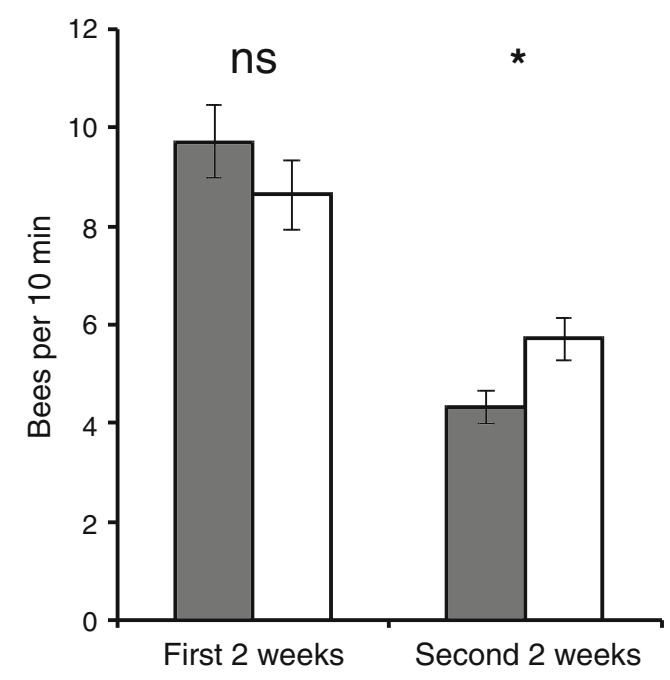

Figure 2. The foraging activity of bumblebee colonies that had been located either near to (gray columns) or far from (white columns) a honeybee apiary $(n=5)$, for 2 or 4 weeks in 2010. Foraging activity was estimated as the number of bees leaving the entrance of the colony in $10 \mathrm{mins}$, based on three, 1-h observations in each 2-week period. A significant difference between columns at $p<0.05$ is indicated by an asterisk.

foraging success as food eventually translates to an increase in the number or weight of bees (adult or brood). This result is consistent with other findings that colonies in an environment with ample resources available can gain more weight than colonies in environments with fewer or less diverse resources (Goulson et al., 2002a; Westphal et al., 2006). The number of foraging trips per colony was not significantly different between the two sites in the first 2 weeks, but was significantly lower in colonies near to the apiary after 4 weeks. This could potentially be due to individual bees taking fewer trips or a smaller proportion of the colony being engaged in foraging, but it seems most likely to be simply due to the smaller size of the colonies near to the apiary. This would explain why there was no difference after 2 weeks but there was after 4 weeks when the colonies at the two sites had diverged more in size.

Data from our study showed that bumblebee workers were lighter in colonies near honeybee hives, while a previous study has found them to be smaller (Goulson and Sparrow, 2009). Lighter, or smaller, workers are less efficient at collecting food than heavier or larger workers (Goulson et al., 2002b; Peat et al., 2005a). This could be due to larger workers being better at locating floral resources, spending less time flying to patches, having a shorter handling time, or being better able to forage in cooler weather (Spaethe and Weidenmüller, 2002; Peat et al., 2005b). Worker body size could therefore provide a meaningful indicator of food availability during the larval stage (Couvillon and Dornhaus, 2009), with a colony with lighter workers being likely to grow less. The other negative impact honeybees could have on bumblebee colony growth, in addition to food depletion, is transmission of parasites or pathogens from honeybees to bumblebees (Genersch et al. 2006; Graystock et al. 2013b). Due to encounters during foraging, bumblebees could run particular risks of acquiring infections from honeybees if pathogens are transmitted when sharing flowers (Durrer and Schmid-Hempel, 1994).

Colonies close to honeybee hives produced significantly fewer, smaller, and lighter queens in 2010, and the data suggested similar effects in 2012 although the result in this year was only significant for the size of queens. Thomson (2004) also found that the number and size of queens was negatively correlated with proximity to honeybee colonies. The lower number of queens produced should lead to fewer new colonies being established in the following year, although the precise relationship between queen numbers and population dynamics in bumblebees is still uncertain. However, not only the quantity of queens produced, but also the quality of these queens is important for colony reproductive success. Queen body size and fat content are important predictors of hibernation success (Holm, 1972; Owen, 1988; Beekman et al., 1998; Inoue, 2011). The weight/size ratio of queens was significantly lower in colonies close to the apiary than those far from the apiary, suggesting that proximity to honeybee hives reduced the quantity of fat in bumblebee queens, which in turn, means that it could have 
impacted negatively on successful colony foundation in the next spring. Another potential impact of the honeybees is a change in colony sex investment ratio. As queens require a greater investment of resources to produce than males (Beekman and van Stratum, 1998), the hypothesis is that colony sex investment ratios should become more male biased in colonies under stress (e.g., close to the honeybee apiary). Our results are consistent with this hypothesis as, in both years, the male/female ratio was significantly higher in the colonies close to than far from the apiary.

In conclusion, the results suggest that honeybees may have a considerable negative influence on the reproductive success of bumblebees, with consequent implications for their population dynamics. Although it cannot be excluded that some other unknown difference between the sites was involved, their similarity makes it seem most likely that the presence of honeybees was responsible for the reduced fitness of bumblebee colonies located close to the apiary. Being based on a comparison of only two sites, this conclusion is obviously very preliminary, and data from many more sites will be needed to confirm the generality of the effect. Although the introduction of honeybees to an area may increase the number of bees on flowers, there is mounting evidence that in many agricultural systems, it is not just the number of pollinators, but also their diversity that determines the pollination services provided (Garibaldi et al., 2011; 2013). The pollination benefit gained by introducing honeybees may therefore be counteracted by the negative effects they have on wild pollinators in the area.

\section{ACKNOWLEDGMENTS}

We are grateful to Holly Mottershead, Chris Wright and Martin Lappage for assistance with field work, and the two anonymous reviewers for their constructive comments. This research was funded by the Higher Education Ministry of Libya.

Effet de la présence proche d'un rucher d'abeilles sur une colonie de bourdons en terme de santé, développement et performance
Écologie / pollinisateur / compétition interspécifique / Bombus terrestris / Apis mellifera

Der Effekt der Nähe zu einem Bienenstand auf die Fitness, die Entwicklung und die Leistungsfähigkeit von Hummelkolonien

Bestäuberökologie / Wettbewerb / Bienen / Bombus terrestris / Apis mellifera

\section{REFERENCES}

Beekman, M., Van Stratum, P. (1998) Bumblebee sex ratios: why do bumblebees produce so many males? Proc. R. Soc. Lond. B 265, 1535-1543

Beekman, M., Van Stratum, P., Lingeman, R. (1998) Diapause survival and post-diapause performance in bumblebee queens (Bombus terrestris). Entomol. Exp. Appl. 89, 207-214

Blanckenhorn, W.U. (2000) The evolution of body size: what keeps organisms small? Q. Rev. Biol. 75, 385407

Butz Huryn, V.M. (1997) Ecological impacts of introduced honey bees. Q. Rev. Biol. 72, 275-297

Cameron, S.A., Lozier, J.D., Strange, J.P., Koch, J.B., Cordes, N., Solter, L.F., Griswold, T.L. (2011) Patterns of widespread decline in North American bumblebees. Proc. Natl. Acad. Sci. USA 108, 662667

Colla, S.R., Packer, L. (2008) Evidence for decline in eastern North American bumblebees (Hymenoptera: Apidae), with special focus on Bombus affinis Cresson. Biodivers. Conserv. 17, 1379-1391

Corbet, S.A., Saville, N.M., Fussell, M., Prys-Jones, O.E., Unwin, D.M. (1995) The competition box: a graphical aid to forecasting pollinator performance. J. Appl. Ecol. 32, 707-719

Couvillon, M.J., Dornhaus, A. (2009) Location, location, location: larvae position inside the nest is correlated with adult body size in worker bumble-bees (Bombus impatiens). Proc. Biol. Sci. B 276, 24112418

Denno, R.F., Mcclure, M.S., Ott, J.R. (1995) Interspecific interactions in phytophagous insects: competition reexamined and resurrected. Annu. Rev. Entomol. 40, 297-331

Durrer, S., Schmid-Hempel, P. (1994) Shared use of flowers leads to horizontal pathogen transmission. Proc. R. Soc. Lond. B 258, 299-302

Fontaine, C., Dajoz, I., Meriguet, J., Loreau, M. (2006) Functional diversity of plant-pollinator interaction webs enhances the persistence of plant communities. PLoS Biol. 4, 129-135

Garibaldi, L.A., Steffan-Dewenter, I., Kremen, C., Morales, J.M., Bommarco, R., et al. (2011) Stability 
of pollination services decreases with isolation from natural areas despite honey bee visits. Ecol. Lett. 14, 1062-1072

Garibaldi, L.A., Steffan-Dewenter, I., Winfree, R., Aizen, M.A., Bommarco, R., et al. (2013) Wild pollinators enhance fruit set of crops regardless of honey bee abundance. Science 339, 1608-1611

Genersch, E., Yue, C., Fries, I., De Miranda, J.R. (2006) Detection of deformed wing virus, a honey bee viral pathogen, in bumble bees (Bombus terrestris and Bombus pascuorum) with wing deformities. J. Invertebr. Pathol. 91, 61-63

Ginsberg, H.S. (1983) Foraging ecology of bees in an old field. Ecology 64, 165-175

Goulson, D. (2004) Keeping bees in their place: impacts of bees outside their native range. Bee World $\mathbf{8 5}$, 45-46

Goulson, D., Sparrow, K. (2009) Evidence for competition between honeybees and bumblebees; effects on bumblebee worker size. J. Insect Conserv. 13, 177181

Goulson, D., Hughes, W.O.H., Derwent, L.C., Stout, J.C. (2002a) Colony growth of the bumblebee, Bombus terrestris, in improved and conventional agricultural and suburban habitats. Oecologia 130, 267-273

Goulson, D., Peat, J., Stout, J.C., Tucker, J., Darvill, B., Derwent, L.C., Hughes, W.O.H. (2002b) Can alloethism in workers of the bumblebee, Bombus terrestris, be explained in terms of foraging efficiency? Anim. Behav. 64, 123-130

Graystock, P., Yates, K., Evison, S.E.F., Darvill, B., Goulson, D., Hughes, W.O.H. (2013a) The Trojan hives: pollinator pathogens, imported and distributed in bumblebee colonies. J. Appl. Ecol. 50, 12071215

Graystock, P., Yates, K., Darvill, B., Goulson, D., Hughes, W.O.H. (2013b) Emerging dangers: deadly effects of an emergent parasite in a new pollinator host. J. Invert. Pathol. 114, 114-119

Gross, C.L. (1993) The breeding system and pollinators of Melastoma affine (Melastomataceae); a pioneer shrub in tropical Australia. Biotropica 25, 468-474

Holland, J., Guidat, F.S., Bourke, A.F.G. (2013) Queen control of a key life-history event in a eusocial insect. Biol. Lett. 9, 20130056

Holm, S.N. (1972) Weight and life length of hibernating bumble bee queens (Hymenoptera: Bombidae) under controlled conditions. Insect Syst. Evol. 3, 313320

Inoue, M.N. (2011) Size-dependent selection against small queens of the invasive bumblebee Bombus terrestris in Japan. Entomol. Exp. Appl. 138, 6570

Kosior, A., Celary, W., Olejniczak, P., Fijal, J., Król, W., Solarz, W., Plonka, P. (2007) The decline of the bumble bees and cuckoo bees (Hymenoptera: Apidae: Bombini) of Western and Central Europe. Oryx 41, 79-88
Oldroyd, B.P., Lawler, S.H., Crozier, R.H. (1994) Do feral honey bees (Apis mellifera) and regent parrots (Polytelis anthopeplus) compete for nest sites? Aust. J. Ecol. 19, 444-450

Owen, R.E. (1988) Body size variation and optimal body size of bumble bee queens (Hymenoptera: Apidae). Can. Entomol. 120, 19-27

Paini, D.R. (2004) Impact of the introduced honey bee (Apis mellifera) (Hymenoptera: Apidae) on native bees: a review. Austral Ecol. 29, 399-407

Peat, J., Darvill, B., Ellis, J., Goulson, D. (2005a) Effects of climate on intra- and interspecific size variation in bumble-bees. Funct. Ecol. 19, 145-151

Peat, J., Tucker, J., Goulson, D. (2005b) Does intraspecific size variation in bumblebees allow colonies to efficiently exploit different flowers? Ecol. Entomol. 30, 176-181

Roubik, D.W. (1983) Experimental community studies: time-series tests of competition between African and neotropical bees. Ecology 64, 971-978

Roubik, D.W., Wolda, H. (2001) Do competing honey bees matter? Dynamics and abundance of native bees before and after honey bee invasion. Popul. Ecol. 43, 53-62

Schaffer, W.M., Zeh, D.W., Buchmann, S.L., Kleinhans, S., Schaffer, M.V., Antrim, J. (1983) Competition for nectar between introduced honey bees and native North American bees and ants. Ecology 64, 564577

Spaethe, J., Weidenmüller, A. (2002) Size variation and foraging rate in bumblebees (Bombus terrestris). Insectes Soc. 49, 142-146

Sugden, E.A., Pyke, G.H. (1991) Effects of honey bees on colonies of Exoneura asimillima, an Australian native bee. Aust. J. Ecol. 16, 171-181

Sugden, E.A., Thorp, R.W., Buchmann, S.L. (1996) Honey bee-native bee competition: focal point for environmental change and apicultural response in Australia. Bee World 77, 26-44

Szabo, N.D., Colla, S.R., Wagner, D.L., Gall, L.F., Keer, J.T. (2012) Do pathogen spillover, pesticide use, or habitat loss explain recent North American bumblebee declines? Cons. Lett. 5, 232-239

Thomson, D. (2004) Competitive interactions between the invasive European honey bee and native bumble bees. Ecology 85, 458-470

Thomson, D.M. (2006) Detecting the effects of introduced species: a case study of competition between Apis and Bombus. Oikos 114, 407-418

Thornhill, R., Alcock, J. (2000) The evolution of insect mating systems. Harvard Univ. Press, Cambridge

Walther-Hellwig, K., Fokul, G., Frankl, R., Büchler, R., Ekschmitt, K., Wolters, V. (2006) Increased density of honeybee colonies affects foraging bumblebees. Apidologie 37, 517-532 
Wenner, A.M. (1992) Removal of feral honey bee (Apis mellifera) colonies from Santa Cruz Island. In: Halverson, W.L., Maender, G.J. (eds.) Fourth California Islands Symposium: Update on the Status of Resources, pp. 351-365. Santa Barbara Mus. Nat. Hist, Santa Barbara

Westphal, C., Steffan-Dewenter, I., Tscharntke, T. (2006) Foraging trip duration of bumblebees in relation to landscape-wide resource availability. Ecol. Entomol. 31, 389-394

Williams, P.H., Osborne, J.L. (2009) Bumblebee vulnerability and conservation world-wide. Apidologie 40, 367-387

Wilms, W., Wiechers, B. (1997) Floral resource partitioning between native Melipona bees and the introduced Africanized honey bee in the Brazilian Atlantic rain forest. Apidologie 28, 339-355 